\title{
Healthcare Encounters Start Date Time
}

National Cancer Institute

\section{Source}

National Cancer Institute. Healthcare Encounters Start Date Time. NCI Thesaurus. Code C124009.

The date and time a healthcare encounter began. 